"Factors affecting equity mutual fund performance: evidence from Indonesia"

\begin{tabular}{|c|c|}
\hline \multirow{3}{*}{ AUTHORS } & Gusni (iD http://orcid.org/0000-0001-7776-8489 \\
\hline & Silviana (D http://orcid.org/0000-0003-3209-5764 \\
\hline & Faisal Hamdani (D http://orcid.org/0000-0002-6036-3802 \\
\hline ARTICLE INFO & $\begin{array}{l}\text { Gusni, Silviana and Faisal Hamdani (2018). Factors affecting equity mutual fund } \\
\text { performance: evidence from Indonesia. Investment Management and Financial } \\
\text { Innovations, 15(1), 1-9. doi:10.21511/imfi.15(1).2018.01 }\end{array}$ \\
\hline DOI & http://dx.doi.org/10.21511/imfi.15(1).2018.01 \\
\hline RELEASED ON & Wednesday, 03 January 2018 \\
\hline RECEIVED ON & Monday, 26 June 2017 \\
\hline \multirow[t]{2}{*}{ ACCEPTED ON } & Friday, 13 October 2017 \\
\hline & $(c c)$ EY-No \\
\hline LICENSE & $\begin{array}{l}\text { This work is licensed under a Creative Commons Attribution-NonCommercial } 4.0 \\
\text { International License }\end{array}$ \\
\hline JOURNAL & "Investment Management and Financial Innovations" \\
\hline ISSN PRINT & $1810-4967$ \\
\hline ISSN ONLINE & $1812-9358$ \\
\hline PUBLISHER & LLC "Consulting Publishing Company "Business Perspectives" \\
\hline FOUNDER & LLC "Consulting Publishing Company "Business Perspectives" \\
\hline
\end{tabular}

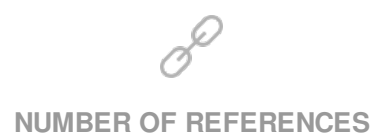

38

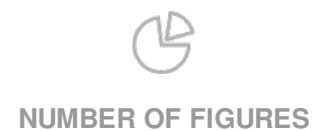

0

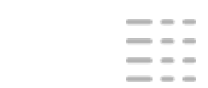

NUMBER OF TABLES

3

(C) The author(s) 2023. This publication is an open access article. 


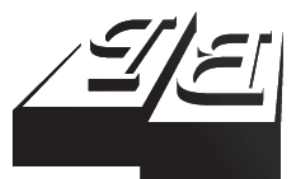

BUSINESS PERSPECTIVES

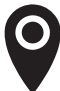

LLC "CPC "Business Perspectives" Hryhorii Skovoroda lane, 10, Sumy, 40022, Ukraine

www.businessperspectives.org

Received on: $26^{\text {th }}$ of June, 2017 Accepted on: $13^{\text {th }}$ of October, 2017

(C) Gusni, Silviana,

Faisal Hamdani, 2018

Gusni, MBA, Widyatama University, Indonesia.

Silviana, Ph.D., Widyatama University, Indonesia.

Faisal Hamdani, S.E., Widyatama University, Indonesia.

\section{(ㄷ)(1) $(8)$}

This is an Open Access article, distributed under the terms of the Creative Commons Attribution-NonCommercial 4.0 International license, which permits re-use, distribution, and reproduction, provided the materials aren't used for commercial purposes and the original work is properly cited.

\title{
FACTORS AFFECTING EQUITY MUTUAL FUND PERFORMANCE: EVIDENCE FROM INDONESIA
}

\begin{abstract}
The evaluation of equity mutual fund performance and identification factors that affect mutual fund performance is of great interest to an investor in Indonesia. This study investigates the performance of equity mutual fund by using risk-adjusted performance proposed by Treynor (1965) and examines factors affecting mutual fund performance by using the ability of investment manager (market timing and stock selection skill), fund size, and inflation. To achieve the objectives of this study, a total of 19 equity mutual funds was selected using purposive sampling method from the period from 2011 to 2015. A panel data analysis method has been used to analyze the effect of those factors on the equity mutual fund performance. The result showed that equity mutual fund performance tends to fluctuate in Indonesia. Equity mutual fund performance influenced by stock selection skill and inflation, meanwhile, market timing skill and fund size have no significant effect on the equity mutual fund performance.
\end{abstract}

Keywords

\section{JEL Classification}

\section{INTRODUCTION}

Mutual funds play an important role in the Indonesian economy and are the investment instrument used by society. Mutual funds are a pool of money and managed by investment companies. This type of investment is known to have low transaction costs, portfolio diversification and managed by a professional investment manager. Now mutual funds have become one of strategic investment activities especially for small investors who don't have time and expertise in calculating their investment risk and return (Pangestuti, Wahyudi, \& Robiyanto, 2017).

In Indonesia, the mutual fund started at 1976, set up and managed by the government through PT. Danareksa by issuing Danareksa I and II certificates. Indonesia Financial Service Authority reported the mutual fund rapid growth and until now, there are 1,589 schemes that are actively managed by 85 investment managers with a total fund more than IDR 338 trillion. The type of mutual fund portfolio traded consists of money market, equity, fixed income, mixed, protected, guaranteed and index mutual funds. Equity mutual fund is the most preferred by an investor mutual fund with total investment in assets of about $32.74 \%$. High interest of investor in equity mutual fund pushed by the higher expectation of investment return compared to another type of mutual fund portfolio. Therefore, investors expect the good equity mutual fund performance over time. 
The evaluation of equity mutual fund performance and identification of determinants of it are of great interest to the investor. There have been many previous studies discussed of the performance evaluation of mutual funds that have an important role in the expansion of financial literature. The traditional method of funds evaluation based on risk-adjusted performance comes from Treynor (1965), Sharpe (1966) and Jensen (1968). Each of this performance evaluation method has its advantage and disadvantage. Evaluation method used in this study is Treynor method. Research conducted by Prajapati and Patel (2012) found that Treynor method is better than Sharpe and Jensen method in evaluating mutual fund performance. Hereafter, research conducted by Alptekin (2009) found that Treynor, Sharpe, and Jensen method in evaluating mutual fund performance give relatively the same result. Treynor was the first researcher to evaluate fund performance in relation to risk with beta and measure portfolio market risk premium towards beta (See \& Jusoh, 2012).

Mutual fund performance change occurs every time affected by various factors, also called mutual fund characteristics or determinants of mutual fund that is (1) investment manager such as gender, experience, graduates, etc., (2) mutual fund factors such fund age, fund size, fund type, and others, (3) investor behavior (Alexandri, 2013). In addition to the above factors, macroeconomic factors like inflation, exchange rate, and others also are believed to have an effect on the mutual fund performance (Monjazeb \& Ramazanpour, 2013).

Investment manager ability is one of the factors that can improve mutual fund performance (Naveen \& Mallikarjunappa, 2016). Chen et al. (2013) argue that stock selection skill and market timing are two aspects that can explain mutual fund investment manager ability in managing investor portfolio and generating higher returns. Stock selection skills include estimation of individual stock price movements relative to the market and identification of individual stocks that overvalued and undervalued relative to the equity in general (Chen et al., 2013). Market timing strategy can be explained as a strategy for choosing the right instant investment in its simplest form (Rijwani, 2014).

Fund size is also predicted to have an effect the performance of the mutual fund. Large mutual fund size can reduce mutual fund performance related to cost, liquidity and price impact (Perold \& Salomon, 1991). These statements endorsed by Grinblatt and Titman (1989) show that mutual fund return will decline by using large funds. Chen et al. (2004) also consistent with Perold and Salomon (1991) found that fund size erodes performance of mutual fund industry due to liquidity and organizational diseconomies. Yan (2008) found a negative relationship between fund size and fund performance. Different opinion is stated by Amenc and Martellini (2004), Liang (1999) who found a positive relationship between fund size and mutual fund performance.

Inflation is a macroeconomic variable which also has a relationship with mutual fund performance. High inflation rate indicates that the risks to invest are large enough, and due to high inflation will reduce investor rate of return (Adrangi, Chatrath, \& Sanvicente, 1998). This theory supported by a number of researchers like Singh, Mehta, and Varsha (2011), Hermawan and Wiagustini (2016) showed that there is a negative relationship between inflation and mutual fund performance. This research is contradictory with research by Monjazeb and Ramazanpour (2013) who found that inflation has a positive effect on mutual fund performance. Meanwhile, Pasaribu and Kowanda (2014) found that there is no effect of inflation on the mutual fund performance.

Based on the above explanation, we can notice that the existing literature still cannot provide certain factors that affect equity mutual fund performance, therefore it is still interesting to analyze. This research is expected to contribute to the equity mutual funds investors in making an investment decision and be a reference for the equity mutual funds managers in increasing equity mutual fund performance in Indonesia. 


\section{LITERATURE REVIEW}

A series of empirical studies has been conducted to establish factors affecting equity mutual fund performance. Some of literature focuses on funds managers' ability (stock selection and market timing skill). The pioneering research in this field was done by Treynor and Mazuy (1966). They developed a model to test fund manager abilities by using market timing skill and found that only 57 funds were affected by market timing skill from the total sample used. Next research was conducted by Henriksson and Merton (1981), they found that only 116 funds from 1984 sample used were significantly affected by market timing skill. Cuthbertson and Nitzsche (2013) also found that market timing skill has a positive effect and stock selection skill has a negative effect on the mutual fund performance in Germany. Sehgal and Jhanwar (2008) found that market timing skill has a positive effect and stock selection skill has no effect on the mutual fund performance in India. Research conducted by Chen et al. (2013), on the contrary, showed that market timing has no effect and stock selection skill has a positive effect on the mutual fund performance in Taiwan. Research conducted by Chang and Lewellen (1984) also showed weak evidence of impact of market timing on the mutual fund performance. Chang and Lewellen (1985) also found that only 2 funds from 67 funds were significantly affected by stock selection skill. Ferson and Schadt (1996) said that standard performance measures using stock selection and market timing skills are still biased. Therefore funds managers ability and it's relation with fund performance are still big questions to be answered.

A few literatures try to explain relation between fund size and mutual fund performance. Grinblatt and Titman (1989) found mixed evidence that fund return will decrease with fund size. This statement is supported by Perold and Salomon (1991). Agarwal, Daniel, and Naik (2004), Füss, Kaiser, and Strittmatter (2009), Herzberg and Mozes (2003), and Yan (2008) also found a negative relationship between funds size and the mutual funds performance. Bodson, Cavenaile, and Sougné (2011) argue that there is a relationship between fund size and mutual funds performance and that it is quadratic and concave. Furthermore, Clark (2003), Gregoriou and Rouah (2002) didn't find relationship between fund size and the mutual fund performance.
Contradictory conclusions of prior research about fund size begin from a failure to recognize diminishing returns to scale in active investment management. The cost ratio and turnover do not catch all of the transaction costs related with an active investment strategy. Because diseconomies of scale are associated with the costs of researching and trading on information, the economic value added by active management will, as Perold and Salomon (1991) suggested, depend on having the right amount of assets under management (Indro, Jiang, Hu, \& Lee, 1999). Furthermore, fund manager ability and style will significantly influence the right amount of assets to have under management to increase mutual fund performance in generated return.

Inflation is a macroeconomic variable which it believe to have an effect on the mutual fund performance. Several studies try to investigate the relationship between inflation and mutual fund performance. Adrangi, Chatrath, and Sanvicente (1998) mentioned that high inflation rate indicates that the risks to invest are large enough, because high inflation will reduce investor rate of return. Higher rates of inflation may stunt new investments, thus reducing both the aggregate demand and aggregate supply. Therefore, the real output may fall. Singh, Mehta, and Varsha (2011), Hermawan and Wiagustini (2016) show that there is a negative relationship between inflation and mutual fund performance. Meanwhile, Monjazeb and Ramazanpour (2013), and Alexandri (2013) found that there is a significant positive relationship between the fund return and inflation rate in Iran for the period 2008-2011. Pasaribu and Kowanda (2014) mentioned there is no effect of inflation rate to the mutual fund performance. The effect of inflation toward mutual fund performance is still biased, therefore need to be proved.

\section{METHODOLOGY}

\subsection{Data}

This study is explanatory research with a quantitative approach. The data used in this research were secondary data. The data related to net asset value (NAV) of equity mutual fund were gathered from the official website of Financial Service Authority, Jakarta Composite Index gathered from the official website of Indonesia Stock Exchange, Bank 
Indonesia rate and inflation rate gathered from the official we bsite of Bank Indonesia. For additional information, the researcher also takes information which has already existed, like articles, journals, textbooks, etc. This research uses the combination of time series data and cross-section data known as panel data from the period 2011-2015 with the sample taken from 19 equity mutual funds by using purposive sampling technique. Panel data give more informative data, more variability, less collinearity among the variables, more degrees of freedom and more efficiency (Baltagi, 2005).

\subsection{Research variables and hypothesis}

This study focuses on the determinants of equity mutual funds performance (investment manager's ability: market timing and stock selection skill, fund size, and inflation). Equity mutual funds performance as dependent variable is measured by using Treynor method or called Treynor index (Treynor, 1965) as follows:

$$
\text { Treynor }=\frac{R-R_{f}}{\beta_{i}},
$$

where $R$ is expected stock return, $R_{f}$ is the riskfree rate of return and $\beta_{i}$ is stock beta or portfolio beta.

Investment manager's ability is measured by using two variables: market timing and stock selection skill. Market timing skill is measured by using Treynor and Mazuy (1966) method as follows:

$$
\begin{aligned}
& R_{p}-R_{f}=\alpha+\beta \cdot\left(R_{m}-R_{f}\right)+ \\
& +\gamma \cdot\left(R_{m}-R_{f}\right)^{2}+\varepsilon_{p},
\end{aligned}
$$

(2) Refering to Jakarta Composite Index calculation, inflation can be measured as follows: where $R_{p}$ is return of mutual funds portfolio, $R_{f}$ is risk-free return, $R_{m}$ is return on market portfolio, $\alpha$ is intercept, $\beta$ is regression coefficient of excess market return or slope at market time down (bearish), $\gamma$ is regression coefficient that indicates market timing ability of investment managers, $\varepsilon_{p}$ is error term.

Stock selection skill is measured by Treynor and Mazuy (1966) as follows:

$$
\begin{aligned}
& R_{p}-R_{f}=\alpha+\beta \cdot\left(R_{m}-R_{f}\right)+ \\
& +\gamma \cdot\left(R_{m}-R_{f}\right)^{2}+\varepsilon_{p},
\end{aligned}
$$

where $\alpha$ is an intercept that indicates of stock selection skills of investment managers, and others same with the above explanation.

Fund size is measured by using Elton et al. (2014) as follows:

Net Asset Value $=$ Total Asset - Liabilities;

Fund Size $=$ Ln Net Asset Value

Inflation measure is based on Jakarta Composite Index (JCI) that can be calculated as follows:

$$
\mathrm{JCIn}=\frac{\sum P_{n}}{\sum P_{0}} \cdot 100 \%,
$$

\begin{tabular}{|c|c|c|}
\hline Variables & Symbol & Expected sign \\
\hline \multicolumn{3}{|c|}{ Independent variables } \\
\hline Market timing skill & MTS & $\mathrm{H} 1(+)$ \\
\hline Stock selection skill & SSS & $\mathrm{H} 2(+)$ \\
\hline Fund size & FSZ & $\mathrm{H} 3(-)$ \\
\hline Inflation & INF & $\mathrm{H} 4(-)$ \\
\hline \multicolumn{3}{|c|}{ Dependent variable } \\
\hline Equity mutual fund performance & EMP & - \\
\hline
\end{tabular}

where JCIn was Jakarta Composite Index current year, $\sum P_{n}$ was the sum of price at current year, and $\sum P_{0}$ was the sum of price at basic year.

Table 1. Research variables and hypotheses 


$$
\text { Inflation }=\frac{\mathrm{JCIn}-\mathrm{JCIo}}{\mathrm{JCIo}} \cdot 100 \% \text {. }
$$

The review of several prior studies has resulted in several testable hypotheses. Table 1 shows an overview of the variables used, definition of variables employed and the hypotheses formulated.

\subsection{Empirical model and data analysis method}

In the way to test the hypothesis proposed in this research panel data regression model with regression equation model were used as presented below:

$$
\begin{aligned}
& E M P=\alpha+\beta_{1} \cdot M T S+\beta_{2} \cdot S S S+ \\
& +\beta_{3} \cdot F S Z+\beta_{4} \cdot I N F+e,
\end{aligned}
$$

where $\alpha$ is the constant, $\beta_{1}, \beta_{2}, \beta_{3}, \beta_{4}, \beta_{5}$ are regression coefficients, and the variables already being defined in Table 1 above.

The primary step in using panel data regression model was performing several classical assumption tests consisting of normality, multicollinearity, autocorrelation, and heteroscedasticity test. The purpose of classical assumption test is to make sure that regression equation model has accuracy in estimation, unbiased and consistent.

Next step was Chow, Hausman, and Lagrange Multiplier tests to select an appropriate regression model to this study. Chow test was used to select common effect model or fixed effect model appropriate to this research. Hausman test was used to choose fixed effect model or random effect model appropriate to this study. Lagrange Multiplier test was used to make sure that common effect model or random effect model is appropriate to this research.
After choosing the appropriate model for this research, we performed the test of the accuracy of the regression model in predicting the value of the dependent variable determined by the goodnessof-fit test. In measuring the goodness-of-fit, a panel data regression model can be analyzed through $F$-test and adjusted $R^{2} . F$-test is known as ANOVA test, used to find the linear relationship between independent variables with dependent variable or to test if the model used is fixed or not (Lind, Marchal, \& Wathen, 2012). $R^{2}$-test which is a coefficient determination test to measure the ability of the independent variables is used to define changes in the dependent variable.

Next test is t-test or hypothesis test, used to analyze the impact of each independent variable individually on the dependent variable or to answer the entire hypothesis proposed in this research.

\section{EMPIRICAL RESULTS}

\subsection{Descriptive statistics}

Table 2 gives a brief summary of descriptive statistics of variables. The mean value of market timing skill is -3.7074 . The average value of stock selection skill is -0.0002 , fund size is 8.8105 , and inflation is 0.0564 . The average value of equity mutual fund performance is -0.0157 . These results indicate that the average of sample equity mutual funds used in this research has a poor performance.

\subsection{Regression results}

According to the classical assumption, test result explains that the data are normally distributed based on skewness and kurtosis ratio resulted between -2 to $+2(-0.266$ and 1.578$)$. There is no

\begin{tabular}{|c|c|c|c|c|c|}
\hline Variables & Mean & Median & Std. dev. & Max. & Min. \\
\hline EMP & -0.01571 & -0.031232 & 0.145156 & 0.50291 & -0.33038 \\
\hline MTS & -3.70737 & -0.475821 & 31.05863 & 96.82582 & -119.91940 \\
\hline SSS & -0.00024 & -0.001252 & 0.007269 & 0.05401 & -0.01248 \\
\hline FSZ & 8.81049 & 8.458579 & 1.074259 & 11.20784 & 7.31183 \\
\hline INF & 0.05636 & 0.043000 & 0.022644 & 0.08380 & 0.03350 \\
\hline
\end{tabular}

Table 2. Descriptive statistics of equity mutual funds

Source: Financial Service Authority, Indonesia Stock Exchange and Bank of Indonesia (processing data). 
Table 3. Panel data regression results

Source: Financial Service Authority, Indonesia Stock Exchange and Bank of Indonesia (processing data).

\begin{tabular}{l|c|c|c}
\hline \multicolumn{1}{c|}{ Variables } & Coefficient & t-statistic & Prob. \\
\hline MTS & -0.000213 & -0.307497 & 0.7592 \\
\hline SSS* & 9.237922 & 3.174032 & 0.0021 \\
FSZ & 0.023794 & 0.734402 & 0.4646 \\
\hline INF* & 3.188424 & -873390 & 0.0002 \\
Adjusted R-squared & 0.289577 & - & - \\
\hline F-statistic & 10.47697 & - & - \\
Prob (F-statistic) & 0.000001 & - & - \\
\hline
\end{tabular}

Note: ${ }^{\star}$ significant at $5 \%$.

multicollinearity problem due to the result of coefficient correlation are below 0.8 for all independent variables. For the autocorrelation, test result indicates that the data have autocorrelation problem. Even so, the model still can be used for the next analysis refering to Basuki and Yuliadi (2015) who mention that autocorrelation test is only suitable for time series data, while it is useless for panel data. The result of heteroskedasticity test using the Breusch Pagan Godfrey (BPG) test show that $p$-value-obs ${ }^{*}$-square $0.2843>0.05$, which means there is no heteroscedasticity among the residuals in the regression model or the variance of the residuals keeps staying the same across different observations or different values of independent variables.

The regression equation in this research is formed by using random effect model which was selected through Chow test, Hausman test, and Lagrange Multiplier (LM) tests. The results of the regression are shown in Table 3 above.

The results of the regression analysis show that the coefficient of variation $(b)$ which explains the direction of variability is positive for stock selection skill, fund size, and inflation, while it is negative for market timing skill.

$F$-test results shown in the table above show that Prob $(F$-statistic $)=0.000$, which means that indee pendent variables used in this research are able to define dependent variable in a good way or the regression model is fixed.

According to the result of adjusted R-squared, the variation in the equity mutual fund performance can be explained by the variation in market tim- ing and stock selection skill, fund size, and inflation by $28.96 \%$, while the remaining $71.04 \%$ are explained by the variation of other variables outside the regression model.

Hypothesis test results as shown in Table 2 above indicate that only stock selection skill and inflation have a positive effect on the equity mutual funds performance in Indonesia. Meanwhile, market timing skill and fund size do not affect the equity mutual funds performance.

\section{DISCUSSION}

The first hypothesis in this study was market timing skill which has a positive effect on the equity mutual funds performance. The statistical test as shown in Table 3 above indicates that the variable does not have the effect on the equity mutual funds performance. Therefore, the first hypothesis is rejected.

The empirical finding does not reveal any general skill of equity mutual fund managers to time the market correctly. This result is contrary to the theory which said that market timing is one of two aspects that can explain mutual fund investment manager ability to manage investor portfolio and generate higher returns at the right time (Chen et al., 2013). This research is similar to the study conducted by Naveen and Mallikarjunappa (2016), Chen et al. (2013), Chang and Lewellen (1984) who found that there is no effect of market timing skill on the mutual fund performance. This research is contrary with the research conducted by Treynor and Mazuy (1966), Henriksson and Merton 
(1981), Cuthbertson and Nitzsche (2013), Sehgal and Jhanwar (2008) who found that there is an effect of market timing skill on the mutual fund performance.

The second hypothesis was stock selection skill that has a positive effect on the equity mutual fund performance. The result shows that the variable has a positive effect on the equity mutual fund performance. Therefore, the second hypothesis is accepted.

The finding indicates that investment managers ability to manage investment portfolio increases equity mutual fund performance. Stock selection skill indicates the ability of investment managers in choosing the right stock to be included in the portfolio to produce the higher return on investment.

This research is similar to the research by Alexandri (2013), Naveen and Mallikarjunappa (2016) who found that there is a positive effect of stock selection skill on the mutual fund performance and contrary to research conducted by Cuthbertson and Nitzsche (2013) who found that there is a negative effect of stock selection skill on the mutual fund performance. Sehgal and Jhanwar (2008) and Chang and Lewellen (1985) found weak and no effect of stock selection skill on the mutual fund performance.

The third hypothesis was that fund size has a negative effect on the equity mutual fund performance. The empirical result shows that the variable has no effect on the equity mutual fund performance. Therefore, the third hypothesis is rejected.

The large fund size will have low risk compared to small fund size (Elton et al., 2014). This statement is contrary to the argument by Perold and Salomon (1991) who said that large mutual fund size can reduce mutual fund performance related to cost, liquidity and price impact. Grinblatt and Titman (1989) said that mutual fund return will decrease by using large funds. This research is contradictory with the above theory.

This research is similar to the research conducted by Clark (2003), Gregoriou and Rouah (2002) who state that there is no relationship between fund size and equity mutual fund performance. This study is opposite with research conducted by Agarwal et al. (2004), Füss et al. (2009), Herzberg and Mozes (2003), Yan (2008), Bodson, Cavenaile, and Sougné (2011), Amenc and Martellini (2004), Liang (1999), Chen et al. (2004) who found that there is a relationship between fund size and equity mutual fund performance.

The fourth hypothesis was that inflation has a negative effect on the equity mutual fund performance. The statistic results show that the variable has a positive effect on the equity mutual fund performance. Therefore, the hypothesis is rejected.

This finding is interesting because the result indicates that when inflation increases, equity mutual fund performance also increases. This research is contradictory with theory that said that high inflation rate indicates that the risks to invest are large enough which, due to high inflation will reduce investor rate of return (Adrangi et al., 1998).

This study is similar to Alexandri (2013), Monjazeb and Ramazanpour (2013) who found that there is a positive effect of inflation on the equity mutual fund performance. This study is contrary to the research conducted by Singh et al. (2011), Hermawan and Wiagustini (2016) who found that there is a negative effect of inflation on the equity mutual fund performance.

\section{CONCLUSION}

The aim of this study was to examine the determinants of mutual fund performance by using the ability of investment manager (market timing and stock selection skill), fund size, and inflation factors. The data used for this research were secondary data gathered from the official website of Financial Service Authority, Indonesia Stock Exchange, and Bank Indonesia. This research used equity mutual fund listed in Financial Service Authority from the period 2011-2015 with sample were taken from 19 equity mutual funds by using purposive sampling technique. The regression model used in this study was random effect model referring to Chow, Hausman and Lagrange Multiplier test result. 
The regression model used in this research has passed from classical assumption tests except for autocorrelation test, and the empirical result shows that the regression model used is able to describe the dependent variable in a good way or the estimation model is fixed. Adjusted R-square (R2) value indicates that $28.96 \%$ of independent variables are able to explain the percentage of variation in the dependent variable, while the remaining $71.04 \%$ is explained by the variation of other variables outside the regression model.

The hypothesis test results show that only stock selection skill and inflation have a positive effect on the equity mutual fund performance, meanwhile, market timing skill and fund size do not affect the equity mutual funds performance.

There have been several limitations of this research which may affect the research results. First, limitation number of research sample used that is only 18 equity mutual fund listed in Financial Service Authority from the period 2011-2015 that fulfill the criteria which are observed to identify variables that affect equity mutual funds performance. Thus, the researcher suggests that the future research will use a wider research sample and a longer period of time, so the number of observation is bigger and more accurate.

Second, limited number of independent variables used in this research, that is, only 4 variables. Thus, the researcher suggests that the future research will add more independent variables by collaborating with more theories and previous research.

\section{REFERENCES}

1. Adrangi, B., Chatrath, A., \& Sanvicente, A. Z. (1998). Inflation, Output, And Stock Prices: Evidence From Brazil. The Journal of Applied Business Research, 18(1), 61-77. Retrieved from https:// www.cluteinstitute.com/ojs/index. php/JABR/article/view/2101

2. Agarwal, V., Daniel, N. D., \& Naik, N. Y. (2004). Flows, Perfomance, and Managerial Incentives in Hedge Funds (CFR Working Paper, 04-04(501)).

3. Alexandri, M. B. (2013). Analysis of Mutual Fund's Performance and Persistence in Indonesia. International Journal of Science and Research, 6(14), 1404-1408. Retrieved from https://www.ijsr. net/archive/v4i1/SUB15364.pdf

4. Alptekin, N. (2009). Performance Evaluation Of Turkish Type A Mutual Funds and Pension Stock Funds By Using Topics Method. International Journal of Economics And Finance, 1(2), 11-22. Retrieved from http://www. sobiad.org/ejournals/journal_ijef/ archieves/ijef2009/06nesrinalptekin.pdf
5. Amenc, N., \& Martellini, L. (2004). The Alpha and Omega of Hedge Fund Performance Measurement (EDHEC Working Paper, 33).

6. Baltagi, B. H. (2005). Econometric Analysis of Panel Data (3d ed.). England: John Wiley and Sons, Ltd.

7. Bodson, L., Cavenaile, L., \& Sougné, D. (2011). Does size affect mutual fund performance? A general approach. Journal of Asset Management, 12(3), 163171. https://doi.org/10.1057/ jam.2011.30

8. Chang, E. C., \& Lewellen, W. G. (1984). Market Timing and Mutual Fund Investment Performance. The Journal of Business, 57(1), 57-72.

9. Chang, E. C., \& Lewellen, W. G. (1985). An Arbitrage Pricing Approach to Evaluating Mutual Fund Performance. Journal of Financial Research, 8(1), 15-30.

10. Chen, D., Chuang, C.-L., Lin, J.-R., \& Lan, C.-L. (2013). Market Timing and Stock Selection Ability of Mutual Fund Managers in Taiwan: Applying The Traditional and Conditional. International Research Journal of Applied Finance, IV(1), 75-99. Retrieved from https://www.researchgate. net/publication/259472460_Market_Timing_and_Stock_Selection_ Ability_of_Mutual_Fund_Managers_in_Taiwan_Applying_The_ Traditional_and_Conditional_Approaches

11. Chen, J., Hong, H., Huang, M., Kubik, J. D., American, T., Review, E., \& Dec, N. (2004). Does Fund Size Erode Mutual Fund Performance? The Role of Liquidity and Organization. American Economic Review, 94(5), 1276-1302.

12. Clark, A. (2003). Does fund size affect performance? Lipper Research Study, 1-82.

13. Cuthbertson, K., \& Nitzsche, D. (2013). Performance, Stock Selection and Market Timing of the German Equity Mutual Fund Industry. Journal of Empirical Finance, 21(1), 86-101. https://doi. org/10.1016/j.jempfin.2012.12.002

14. Elton, E. J., Gruber, M. J., Brown, S. J., \& Goetzmann, W. N. (2014). 
Modern Portfolio Theory and Investment Analysis (9th ed.). New York: John Wiley and Sons Ltd.

15. Ferson, W. E., \& Schadt, R. W. (1996). Measuring Fund Strategy and Performance in Changing Economic Conditions. The Journal of Finance, 51(2), 425-461.

16. Füss, R., Kaiser, D. G., \& Strittmatter, A. (2009). Measuring Funds of Hedge Funds Performance Using Quantile Regressions: Do Experience and Size Matter? The Journal of Alternative Investments, 12(2), 41-53.

17. Gregoriou, G. N., \& Rouah, F. (2002). Large Versus Small Hedge Funds: Does Size Affect Performance? The Journal of Alternative Investments, 5(3), 75-77.

18. Grinblatt, M., \& Titman, S. (1989). Mutual Fund Performance: An Analysis of Quarterly Portfolio Holdings. The Journal of Business, 62(3), 393-416.

19. Henriksson, R. D., \& Merton, R. C. (1981). On Market Timing and Investment Performance. IL. Statistical Procedures for Evaluating Forecasting Skills. The Journal of Business, 54(4), 513-533.

20. Hermawan, D., \& Wiagustini, N. L. P. (2016). The Effect of Inflation, Interest Rate, Fund Size, and Fund Age to The Mutual Funds Performance. Jurnal Manajemen Universitas Udayana, 5(5), 31063133. Retrieved from https://ojs. unud.ac.id/index.php/Manajemen/article/view/20110

21. Herzberg, M. M., \& Mozes, H. A. (2003). The Persistence of Hedge Fund Risk: Evidence and Implications for Investors. The Journal of Alternative Investments, 6(2), 22-42.

22. Indro, D. C., Jiang, C. X., Hu, M. Y., \& Lee, W. Y. (1999). CFA Institute. Financial Analysts Journal, 55(3), 74-87.
23. Jensen, M. C. (1968). The Performance of Mutual Funds In The Period 1945-1964. The Journal of Finance, 23(2), 389-416.

24. Liang, B. (1999). On the Performance of Hedge Funds. Financial Analysts Journal, 55(4), 72-85.

25. Lind, D. A., Marchal, W. G., \& Wathen, S. A. (2012). Statistical Techniques in Business \& Economics. New York: McGraw-Hill.

26. Monjazeb, M., \& Ramazanpour, E. (2013). The Effect of Economic Factors on the Efficiency of Mutual Funds in Iran. Technical Journal of Engineering and Applied Sciences, 3(15), 17071711. Retrieved from http:// pakacademicsearch.com/pdf-files/ eng/73/1707-1711\%20Volume $\% 20$ 3\%20NO\%2015\%20(2013).pdf

27. Naveen, S., \& Mallikarjunappa, T. (2016). An Empirical Study on Market Timing and Selectivity Skills of Indian Mutual Fund Managers Using Treynor and Mazuy Model. International Journal of Computational Research and Development (IJCRD), 1(1), 58-61.

28. Pangestuti, I. R. D, Wahyudi, S., \& Robiyanto. (2017). Performance Evaluation of Equity Mutual Funds in Indonesia. Jurnal Keuangan dan Perbankan, 21(4), 527-542.

29. Pasaribu, R., \& Kowanda, D. (2014). The effect of Interest Rate, Inflation Rate, Jakarta Composite Index, and Foreign Capital Market to Equity Mutual Funds Rate of Return. Jurnal Akuntansi \& Manajemen, 25(1), 1-17.

30. Perold, A. F., \& Salomon, R. S. (1991). The Right Amount of Assets Under Management. Financial Analysts Journal, 47(3), 31-39.

31. Prajapati, K., \& Patel, M. (2012). Comparative Study on Performance Evaluation of
Mutual Fund Schemes of Indian Companies. Journal of Arts, Science and Commerce, 3(3), 47-59.

32. Rijwani, P. (2014). Stock Selection, Market Timing and Mutual Fund Performance. Indian Journal of Accounting, 46(2), 47-58. Retrieved from http://indianaccounting.org/ downloads/4_STOCK\%20SELECTION,\%20MARKET.pdf

33. See, Y. P., \& Jusoh, R. (2012). Fund Characteristics and Fund Performance: Evidence of Malaysian Mutual Funds. International Journal of Economics and Management Sciences, 1(9), 31-43. Retrieved from https://www.omicsonline. org/open-access/fund-characteristics-and-fund-performanceevidence-of-malaysian-mutualfunds-fund-characteristics-andfund-performance-evidenceof-malaysian-mutual-funds-. php?aid=17203

34. Sehgal, S., \& Jhanwar, M. (2008). On Stock Selection Skills and Market Timing Abilities of Mutual Fund Managers in India. International Research Journal of Finance and Economics, 15, 307-317.

35. Sharpe, W. F. (1966). Mutual Fund Performance. The Journal of Business, 39(1), 119-138.

36. Singh, T., Mehta, S., \& Varsha, M. S. (2011). MacroEconomic Factors and Stock Returns: Evidence from Taiwan. Journal of Economics and International Finance, 2(4), 217-227. Retrieved from http://www.academicjournals.org/article/article1379674468_ Singh\%20et\%20al.pdf

37. Treynor, J. L. (1965). How to Rate Management of Investment Funds. Harvard Business Review, 4(3), 63-75.

38. Yan, X. (Sterling). (2008). Liquidity, Investment Style, and the Relation between Fund Size and Fund Performance. Journal of Financial and Quantitative Analysis, 43(3), 741-768. 